\title{
Foraging activity of the free-tailed bat Molossus molossus (Chiroptera; Molossidae) in southeastern Brazil
}

\author{
Esbérard, CEL. ${ }^{\text {* }}$ and Bergallo, $H G{ }^{\mathrm{b}}$ \\ ${ }^{a}$ Laboratório de Diversidade de Morcegos, Universidade Federal Rural do Rio de Janeiro - UFRPE, \\ CP 74507, CEP 23890-000, Seropédica, RJ, Brazil \\ ${ }^{\text {b}}$ Departamento de Ecologia, Instituto de Biologia - IB, Universidade do Estado do Rio de Janeiro - UERJ, \\ Rua São Francisco Xavier, 524, CEP 20559-900, Rio de Janeiro, RJ, Brazil \\ *e-mail: cesberard@ superig.com.br \\ Received September 16, 2009 - Accepted October 27, 2009 - Distributed November 30, 2010
}

(With 3 figures)

\begin{abstract}
Sunset and sunrise regulate the activities of most studied bat species. To verify patterns of foraging activity, 29 bat sampling nights were carried out over a dam in Rio de Janeiro city, which resulted in 363 hours with 730 captures, representing 13 species of insectivorous bats. Molossus molossus constituted the bulk of the captures (79.9\%) and was present in $82.8 \%$ of the sampling nights. This bat species exhibited crepuscular and nocturnal activity (from -6 minutes to 900 minutes after the time of sunset). A bimodal activity pattern was observed, and two non-overlapping capture peaks. The first peak lasted from 6 minutes before sunset to 420 minutes after sunset. The second peak began at 564 minutes after sunset and ended just after sunrise. The first capture peak was observed in $75.9 \%$ of the nights, and the second peak in $62.1 \%$ of the nights. The time of the first capture exhibited a positive linear relationship with sunset and the time of the last capture, a positive linear relationship with sunrise. The existence of a relationship between night length and the difference between first and last captures of each night shows that $M$. molossus has longer activity the longer the night, showing a seasonal variation in the activity period.
\end{abstract}

Keywords: time budget, behaviour, Atlantic Forest.

\section{Atividade de forrageio do morcego-cauda-de-rato Molossus molossus (Chiroptera; Molossidae) no Sudeste do Brasil}

\section{Resumo}

A atividade dos morcegos inicia-se imediatamente antes, durante ou imediatamente após o pôr do sol. O início e o término das atividades dos morcegos são reguladas respectivamente pelo pôr e nascer do sol. Nesse trabalho, 29 noites de amostragem foram realizadas (total de 363 horas) sobre um açude na Cidade do Rio de Janeiro para avaliar a atividade de forrageio de Molossus molossus. Esse esforço resultou em 730 capturas de 13 espécies de morcegos insetívoros. Molossus molossus constituiu a maior parte das capturas e representou 79,9\% da amostragem, presente em 82,8\% das noites de coleta. Esta espécie apresenta atividade crepuscular e noturna (de -6 minutes a 900 minutos após o pôr do sol). Foi observado um padrão bimodal de atividade com picos de capturas sem superposição, sendo o primeiro 6 minutos antes do pôr do sol a 420 minutos após o pôr do sol, e o segundo aos 564 minutos após o pôr do sol e término imediatamente após o nascer do sol. O primeiro pico de captura ocorreu em 75,9\% das noites e o segundo em $62,1 \%$ das noites. O horário da primeira captura resultou em uma relação linear positiva com o pôr do sol e o horário da última captura, com o nascer do sol. A existência de relação entre a duração da noite e a diferença entre a primeira e a última captura de cada noite demonstra que $M$. molossus tem maior período de atividade quanto mais longa é a noite, sustentando uma variação estacional do período de atividade.

Palavras-chave: atividade horária, comportamento, Mata Atlântica. 


\section{Introduction}

Most bat species start their activities just before, during, or after sunset. The beginning and end of bat activities are regulated by sunset and sunrise, respectively (Erkert, 1982). After a short period of activity, insectivorous bats return to their day roost (Fenton et al., 1998). On some nights, a second period of activity occurs just before sunrise, usually involving a smaller number of animals (Erkert, 1982; Marques, 1986). Insectivorous bats usually restrict their activity to periods of higher insect availability, mainly dusk and dawn (Ransome, 1990; Erkert, 1978, 1982), so a bimodal pattern is often expected (e.g. Cockrum and Cross, 1964; Marques, 1986). Another factor that can explain this bimodal pattern is predation risk. Bats avoid the highest luminosity period due to a higher probability of visuallyoriented predators, such as owls (Jones and Rydell, 1994; Rydell et al., 1996; Kramer and Birney, 2001).

Foraging activity has been studied for Molossus rufus E. Geoffroy, 1805 by Fenton et al. (1998). They found that it lasts on average 26.8 minutes, and bats ingest 4.4 beetle $\mathrm{g} /$ night. However, the length of this foraging activity may be influenced by several factors such as rainfall, wind intensity and insect availability (Lee and McCraken, 2001). Those authors observed that the reproductive condition of Tadarida brasiliensis (I. Geoffroy, 1824), causes an increase in energy requirements especially during pregnancy and lactation, therefore inactive females and males may exhibit shorter foraging periods.

There are few studies analysing bat activity using mist nets frequency of capture. In Brazil, there are the studies of Marques (1986) on the activity of M. molossus in a roost, and that of Almeida et al. (2007) in which an ultrasound detector was used to describe the activity and to compare it in different environments. More recent studies on Molossidae activity have been developed outside Brazil and were based on bat detectors (e.g. Sanderson, 1998), or were carried out near day roosts to analyse the emergence of these animals (Subbaraj and Chandrashekaran, 1977; Bateman and Vaughan, 1974,; Lee and McCraken, 2001).

Mist-netting is the most used method for capturing bats in Brazil (Esbérard and Bergallo, 2005), but its efficiency is very limited for species with a highly-developed sonar, like insectivorous bats (e.g. Voss and Emmons, 1996). However, when mist nets are set over water, it is possible to obtain greater catches of insect-feeding species (Cockrum and Cross, 1964; Esbérard, 2003; Esbérard and Bergallo, 2008; Lourenço et al., 2010). In those environments, efficiency may be increased by the capture of individuals that use these water bodies for foraging or drinking water (Voss and Emmons, 1996; Adams and Simmons, 2002).

The objectives of the present study were to analyse the activity of Molossus molossus (Pallas, 1766) using mist nests opened over water, and to test the relationship between activity and the times of sunset and sunrise.

\section{Material and Methods}

Between 1993 and 1999, bat samplings with nets set over a dam were carried out during non-consecutive nights in an urban park "Parque da Gávea" (23 58' 68.7" S and $\left.43^{\circ} 14^{\prime} 54.3^{\prime \prime} \mathrm{W}\right)$. This dike has an area of $400 \mathrm{~m}^{2}$ and neighbors a secondary forest. For further characteristics of the site see Esbérard (2003) and Esbérard and Bergallo (2008). Each night from seven to ten mist nets $(7 \times 2.5 \mathrm{~m}$, mesh of $20 \mathrm{~mm}$ ) were set at least one hour before sunset, and remained opened until one hour after sunrise.

The exact capture time of each individual was recorded, by using radio communicators operated by the team members who remained next to the nets. Bats were measured, weighed, marked with a tattoo pincher with green India ink, and released from 30 to 60 minutes after capture. Recaptures on the same night were not considered in this analysis.

The capture time of each individual was converted in minutes after sunset and minutes before sunrise. Sunset and sunrise local times were obtained with the software Moonphase Southern Hemisphere 3.0. In order to analyse capture frequency, data were grouped in 30 categories in relation to sunset, starting at -30 and finishing at 900 minutes. A linear regression between capture time and local sunset and sunrise times was estimated in Systat 8.0, considering, respectively, the first and the last capture of each night. To test whether M. molossus has a longer activity period during longer nights, a linear regression between the total in minutes from sunset to sunrise and the difference between the first and the last capture of each night was estimated.

\section{Results}

Samplings were carried out at 29 nights (total of 363 hours), which resulted in 730 captures of 13 different species of insectivorous bats. Molossus molossus represented $79.9 \%$ of the captures at the site $(n=562)$ and was captured in $24(82.8 \%)$ out of 29 samplings nights. This species exhibited a crepuscular and nocturnal activity. The first captures were obtained immediately before sunset ( -6 minutes) and activity ended only after sunrise. There were no captures between 7.0 and 9.40 hours after sunrise (Figure 1). The beginning of the activity period of $M$. molossus was adjusted to local sunset time, with a capture peak 31-60 minutes after sunset, which corresponded to $43.6 \%$ of all captures. A bimodal pattern was observed, with the first peak a few minutes before sunset to 420 minutes after sunset, with a capture average of $74.7 \pm 68.9$ minutes. The second peak started at 564 minutes and finished at 88 minutes after sunrise, with a capture average of $677.3 \pm 69.3$ minutes, including six captures observed after sunrise. The first peak of captures was observed on 22 sampling nights $(75.86 \%)$ and the second peak on 18 nights (62.07\%) (Figure 2). Twenty two recaptures of different nights were observed, out of which fifteen occurred in the first activity period and seven in the second period. Six of them involved 


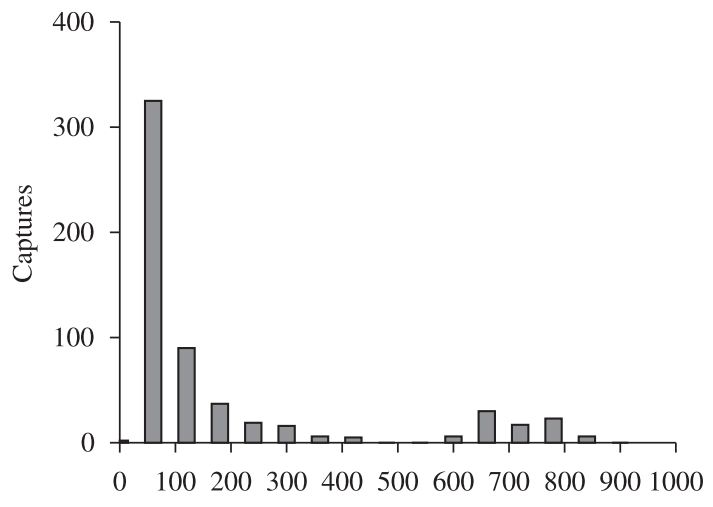

Minutes to sunset time

Figure 1. Observed capture distribution $(\mathrm{n}=562)$ of Molossus molossus in periods of 100 minutes with relation to local sunset time in an urban park in Rio de Janeiro city from 1993 to 1999.

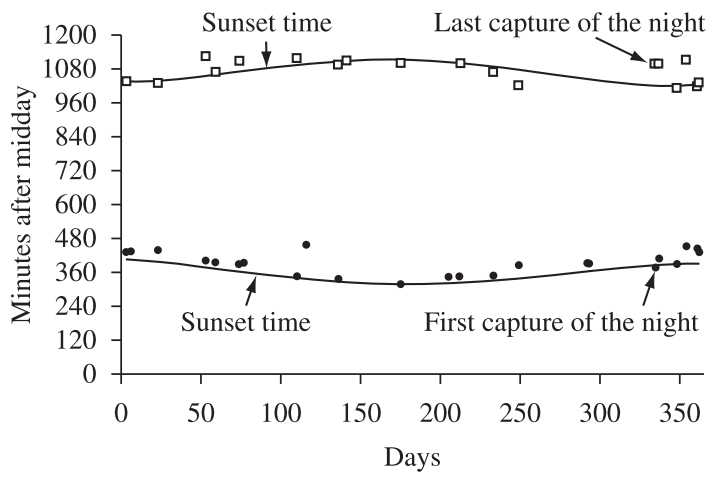

Figure 2. Time of the first and last captures during 24 nights, local sunset and sunrise times for Molossus molossus in Rio de Janeiro city from 1993 to 1999 . Black dots - first capture, white squares - last capture, button line - sunset time in minutes after 12 hours and top line - sunrise in minutes after 12 hours.

animals captured in the first period and recaptured in the second period.

The first capture exhibited a positive relationship with sunset $(r=0.75, F=26.922, p>0.001, N=22)$, and the last capture a positive relationship with sunrise $(\mathrm{r}=0.54$, $\mathrm{F}=30.334, \mathrm{p}>0.001, \mathrm{~N}=18$ ). Molossus molossus exhibited a longer activity period during longer nights $(r=0.79$, $\mathrm{F}=27.884, \mathrm{p}>0.001, \mathrm{~N}=16$ ) (Figure 3).

\section{Discussion}

Twilight length varies geographically and at $23^{\circ} 10^{\prime} \mathrm{S}$, it takes from 23 to 25 minutes for dusk and from 30 to 33 minutes for dawn (Observatório Nacional, 2001). Part of the captures were obtained in sunlight. In most studied bat species, activity is synchronised with sunset (Erkert, 1982; McAney and Fairley, 1988; Isaac and Marimuthu, 1993; Laborda and Cartwright, 1993; Catto et al., 1995; Kunz and Anthony, 1996; Weinbeer et al., 2006).

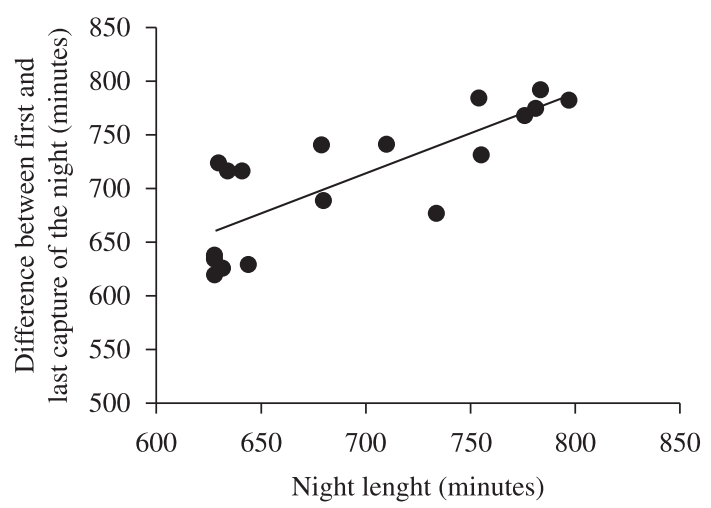

Figure 3. Night length variation and the difference between the first and the last capture $(\mathrm{n}=16)$ for Molossus molossus in Rio de Janeiro city from 1993 to 1999.

A bimodal activity pattern has already been described for M. molossus and M. rufus when emerging from their roosts (Marques, 1986), and for other species of Molossidae and Vespertilionidae as well (Church, 1957; Cockrum and Cross, 1964; Caire et al., 1986; Avery, 1986). Lower prey availability (Hecker and Brigham, 1999) and higher predation risk (Duverge et al., 2000; Kramer and Birney, 2001) may result in activity interruption for part of the night, as observed in this work.

A positive relationship with local sunrise time also suggests that this species prefers to restrict its activity to periods that minimise the probability of attacks by diurnal predators (Isaac and Marimuthu, 1993; Kramer and Birney, 2001; Weinbeer et al., 2006). At 23 degrees of latitude, the night has a variation up to 1.5 hour between the shortest night of summer and the longest night of winter (Observatório Nacional, 2001). Furthermore, the existence of a relationship between night length and the difference between first and last captures of each night shows that M. molossus exhibits longer activity the longer the night, showing a seasonal variation in the activity period.

The first activity peak was more frequent than the second, which is in accordance with previous studies (Marques, 1986; Fenton et al., 1998). Fenton et al. (1998) monitored $M$. rufus with radio telemetry, and noticed that bats performed only one foraging session each night. The few observed recaptures in this work suggest that different individuals have different activity periods at each night, probably maximising activity during periods of high temperature, less wind (e.g. Fenton et al., 1998), higher prey availability or lower predation rates (e.g. Duverge et al., 2000).

Acknowledgements - We are grateful to the management of the "Parque da Gávea" for the license and support with the sampling; C.A.G. Nassar and A.G. Motta for contributions to the manuscript; E.M. Luz, A.S. Chagas, R. Costa, R. Carneiro, R. Cruz, M.S. Nunes, L.F.S. Martins, A. Pol and M.R. Nogueira for support in field work. The samplings were carried out 
according to IBAMA's special permit for samplings (Processes 1785/89-IBAMA and 4156/95-46 AC-SUPES/DF/IBAMA). C.E.L. Esbérard received a productivity fellowship from $\mathrm{CNPq}$ (301061/2007-6) and H.G. Bergallo a productivity fellowship from CNPq (301372/95-0) and Prociência/UERJ.

\section{References}

ADAMS, RA. and SIMMONS, JA., 2002. Directionality of drinking passes by bats at water holes: is there a cooperation? Acta Chiropterologica, vol. 4, no. 2, p. 195-199.

ALMEIDA, H., DITCHIFIELD, A. and TOKUMARU, RS., 2007. Atividade de morcegos e preferência por habitats na zona urbana da Grande Vitória, ES, Brasil. Revista Brasileira de Zoociências, vol. 9 , no. 2 , p. 13-18.

AVERY, MI., 1986. Factors affecting the emergence times of Pipistrelle bats. Journal of Zoology (London), vol. 209, p. 293-296.

BATEMAN, GC. and VAUGHAN, TA., 1974. Nightly activities of mormoopid bats. Journal of Mammalogy, vol. 55, no. 1, p. $45-65$

CAIRE, W., HARDISTY, RM. and LACY, KE., 1986. Ecological notes on Lasiurus cinereus (Chiroptera: Vespertilionidae) in Oklahoma. Proceedings of the Oklahoma Academy of Sciences, vol. 66, p. 41-42.

CATTO, CMC., RACEY, PA. and STEPHENSON, PJ., 1995. Activity patterns of the serotine bat (Eptesicus serotinus) at a roost in southern England. Journal of Zoology (London), vol. 235, p. 635-644.

CHURCH, H., 1957. The time of emergence of Pipristelle. Zoological Society of London, vol. 128, p. 606-608.

COCKRUM, EL. and CROSS, SP., 1964. The bat activity over water holes. Journal of Mammalogy, vol. 45, no. 4, p. 635-636.

DUVERGE, PL., JONES, G., RYDELL, J. and RANSOME, RD., 2000. Functional significance of emergence timing in bats. Ecography, vol. 23, no. 1, p. 32-40.

ERKERT, HG., 1978. Sunset-related timing of flight activity in neotropical bats. Oecologica, vol. 37, p. 59-67.

-, 1982. Ecological aspects of bat activity rhythms. In KUNZ, TH. (Ed.). Ecology of bats. New York: Plenum Press, p. 201-242.

ESBÉRARD, CEL. and BERGALLO, HG., 2005. Research on bats in the state of Rio de Janeiro, southeastern Brazil. Mastozoologia Neotropical, vol. 12, no. 2, p. 237-243.

-, 2008. Do bigger bats need more time to forage? Brazilian Journal of Biology, vol. 68, no. 4, p. 631-637.

ESBÉRARD, CEL., 2003. Diversidade de morcegos em uma área de Mata Atlântica regenerada no sudeste do Brasil (Mammalia: Chiroptera). Revista Brasileira de Zoociências, vol. 5, no. 2, p. 189-204.

FENTON, MB., RAUTENBACH, IL., RYDELL, J., ARITA, HT., ORTEGA, J., BOUCHARD, S., HOVORKA, MD., LIM, B., ODGREN, E., PORTFORS, CV., SCULLY, WM., SYME, DM. and VONHOF, MJ., 1998. Emergence, echolocation, diet and foraging behavior of Molossus ater (Chiroptera: Molossidae). Biotropica, vol. 30, no. 2, p. 314-320.
HECKER, KR. and BRIGHAM, RM., 1999. Does moonlight change vertical stratification of activity by forest dwelling insectivorous bats? Journal of Mammalogy, vol. 80, p. 1196-1201.

ISAAC, SS. and MARIMUTHU, G., 1993. Early outflying and late home-flying in the India Pygmy Bat under natural conditions. Oecologia, vol. 96, p. 426-430.

JONES, G. and RYDELL, J., 1994. Foraging strategy and predation risk as factors influencing emergence time in echolocating bats. Phillosophical Transations of Royal Society of London, series B, vol. 346, p. 445-455.

KRAMER, KM. and BIRNEY, EC., 2001. Effect of light intensity on activity patterns of Patagonian leaf-eared mice, Phyllotis xanthopygus. Journal of Mammalogy, vol. 82, no. 2, p. 535-544.

KUNZ, TH. and ANTHONY, ELP., 1996. Variation in nightly emergence behavior in the little brown bat, Myotis lucifugus (Chiroptera: Vespertilionidae). In GENOWAYS, HH. and BAKER, RJ. (Eds). Contributions in mammalogy: A memorial volume honoring J. Knox Jones, Jr. Lubbock: Texas Tech University Press, p. 225-236.

LABORDA, JA. and CARTWRIGHT, A., 1993. Initial emergence factors of the big brown bat (Eptesicus fuscus). Proccedings of the Indiana Academy of Science, vol. 102, p. 273-277.

LEE, Y. and McCRAKEN, GF., 2001. Timing and variation in the emergence and return of Mexican Free-tailed bats, Tadarida brasiliensis mexicana. Zoological Studies, vol. 40, no. 4, p. 309-316.

LOURENÇO, EC., COSTA, LM., SILVA, RM. and ESBÉRARD, CEL., 2010. Diversidade de morcegos da Ilha da Marambaia, sul do Estado do Rio de Janeiro, Brasil (Chiroptera, Mammalia). Brazilian Journal of Biology, vol. 70, no. 3, p. 511-519.

MARQUES, SA., 1986. Activity cycle, feeding and reproduction of Molossus ater (Chiroptera: Molossidae) in Brazil. Boletim do Museu Paraense Emilio Goeldi, vol. 2, p. 159-179.

McANEY, CM. and FAIRLEY, JS., 1988. Activity patterns of the lesser horseshoe bat Rhinolophus hipposideros at summer roosts. Journal of Zoology (London), vol. 216, p. 325-338.

Observatório Nacional, 2001. Anuário do Observatório Nacional. Available from: <http://perseus.on.br/portuguese/efemerides. html>. Access in: Oct. 2005.

RANSOME, R., 1990. The natural history of hibernating bats. London: Christopher Helm, 235 p.

RYDELL, J., ENTWISTLE, A. and RACEY, PA., 1996. Timing of foraging flights of three species of bats in relation to insect activity and predation risk. Oikos, vol. 76, p. 243-252.

SANDERSON, KJ., 1998. Activity of Chalinolobus gouldii (Gould's wattled bat) during the night at Glenalta (Adelaide Hills), South Australia. South Australian Naturalist, vol. 72, no. 3-4, p. 40-41.

SUBBARAJ, R. and CHANDRASHEKARAN, MK., 1977. 'Rigid' internal timing in the circadian rhythm of flight activity in a tropical bat. Oecologia, vol. 29, p. 341-348

VOSS, RS. and EMMONS, LH., 1996. Mammalian diversity in neotropical lowland rainforests: a preliminary assessment. Bulletin of American Museum Natural History, vol. 230, 115 p.

WEINBEER, M., MEYER, CFJ. and KALKO, EKV., 2006. Activity pattern of the trawling bat, Macrophylum macrophyllum, in Panamá. Biotropica, vol. 38, no. 1, p. 69-76. 